\title{
Capital Adequacy and Financial Performance of Banks in Nigeria: Empirical Evidence Based on the Fgls Estimator
}

\author{
David Umoru, PhD \\ Department of Economics, Banking \& Finance, Benson Idahosa University, \\ Nigeria. \\ Joy O. Osemwegie, MSc \\ Department of Accounting, Benson Idahosa University, Nigeria.
}

doi: 10.19044/esj.2016.v12n25p295 URL:http://dx.doi.org/10.19044/esj.2016.v12n25p295

\begin{abstract}
The study examines the degree of significance of the capital adequacy ratio in influencing the financial deeds of Nigerian banks by applying the feasible GLS estimator technique on the pooled panel model for the period of 2007 to 2015. Empirical evidence supports the overriding impact of capital adequacy in enhancing the financial deeds of Nigerian banks. Nevertheless, the impact of the estimated capital adequacy is below $30 \%$. The policy stance of the empirics holds thus that depositor's money in the banking sector has not been absolutely assured. Hence, the deposit money banks might not be able to fulfil their liabilities and risk. In light of the findings, we suggested a constant reassessment of the least amount of capital required of banks by the CBN.
\end{abstract}

Keywords: Capital adequacy, bank performance, Nigerian deposit money banks

JEL Classification: A46, G28, D62

\section{Introduction}

Banks are financial institutions for mobilizing financial resources through their intermediation role for productive investment (Athansasoglou, Brissimis, and Delis, 2006). Nonetheless, the financial deed of most of the banks in Nigeria over the some years has been unimpressive. The case in point is the fact that the profit before $\operatorname{tax}(P B T)$ of the banking system in Nigeria oscillated between 2000 and 2005, and has since 2006 declined progressively. The $P B T$ which was 80.8 percent in 2000 reduced with a loss value of $13.95 \%$ (Abreu and Mendes, 2002).

Even when the $P B T$ peaked at 287.62 percent in 2007, it further declined to 49.14 percent in 2008 (Obamuyi, 2012). By intuition, the 
environment for Nigerian banks to make profits is sinking. The decline in profits could be attributed to the worldwide economic crises although the in 2005, the Central Bank of Nigeria (CBN) increased the lowest amount of capital that is required by banks to stay in business to N25 billion (Somoye, 2008). So, taking the footsteps of Tomola (2013) that Nigerian banks are yet to in terms of realizing optimal capital structure, the intent of this research is to analyze empirically how significant is adequacy of capital ratio in influencing the deeds of Nigerian banks.

Distinctively, the study intends to evaluate the role of capital adequacy on the performance Nigerian banks. The research hypothesis thus holds that there is no significant effect of capital adequacy on Nigerian banks' performance. Following this introduction, is a review of recent empirical studies on the subject matter. The theoretical framework, model specification, research sample, methodology and data measurement are discussed in section three, section four analyzes the feasible GLS results and section five concludes with emphasis on policy stance.

\section{Empirical studies}

A plethora of studies investigated the link between capital adequacy and bank performance for different countries. To Mpuga (2002), the inadequacy of minimum capital is a major cause of bank failure in Uganda. The empirical evidence of Scott and Arias (2011) supported the fact that capital to asset ratio is a significant profitability determinant of the banks in the United States of America. Vong and Anna (2009) instituted that the bank profitability is a foremost factor for explaining capital strength of a bank.

According to Kosmidou (2008), Saona (2011), Rahman and Farati (2012), there is a considerable positive link between bank profitability and capital adequacy. To Tanaka (2002), monetary channel of influence is watered down if banks are poorly capitalized. Similarly, Sufian (2009) put forth empirically, the significance of capital adequacy of state commercial banks in Bangladesh. Although Riazard and Mehar (2013) found that capital adequacy decreases with bank size and profit is unswervingly linked with capital adequacy, Mathuva (2009) found that bank profitability is positively linked to the core capital ratio and tier one risk based capital ratio.

Ho and Hsu (2010) reported that the limits on capital adequacy have induced banks' risky investment in Japan. In Turkey, Isik and Hassan (2003a) ascertained that capital ratio is absolutely linked to bank profitability whereas inflation has an inverse link. The empirical evidence of Perera, Skully, and Chaudrey (2013) holds that adequate capital was a significant driver of banks profitability. This was corroborated by the empirical evidence from Jordan as Al-Sabbah (2004) found capital adequacy as the most significant and positive determinant of banks' profitability in Jordan. 
The empirics of Dore (2013) found that capital adequacy and liquidity of banks are negatively associated with bank profitability. Neceur (2003) standardized a strong positive impact of capitalization on return on assets of the bank and found that capital adequacy increases the profitability in Tunisia. To Yudistira (2003), there is a strapping absolute link between bank capital and bank deposits in Indonesian. In their research, Somoye (2008), Osuka and Richard (2013) ascertained that asset quality has no link with capital base of the Nigerian banks.

\section{Theoretical framework, model specification and research methodology}

The commercial loan theory drives this study. The nitty-gritty of the theory is that bank funds should be invested in short term loans otherwise known as self-liquidation loans in order to boost working capital. The pooled effect regression model is thus specified:

$$
q_{i t}=\delta_{1}+\sum_{j=2}^{k} \delta_{j} Y_{j i t}+\sum_{f=1}^{p} \phi_{f} Z_{f i}+\beta_{t}+u_{i t}
$$

The index $i$ dictates the unit of observation deposit money bank, $t$ dictates the time period, and $j$ and $f$ are used to distinguish between observed and unobserved regressors, $q$ is the variable of return on asset [ $\operatorname{Ln}(r)]$ or bank profit after tax [Ln(b)],Yj is the vector of capital adequacy ratio [Ln(c)], liquidity [Ln(l)], asset quality [Ln(a)], management efficiency $[\operatorname{Ln}(m)]$ and inflation $[\operatorname{Ln}(n)]$, while the $Z_{f}$ variables are answerable to unobserved heterogeneity and as such constitute a nuisance component of the model. Since the $Z_{f}$ variables are unobserved, we define the unobserved effect, representing the combined impact of the $Z_{f}$ variables on $q_{i}$ as $w_{i}$.

$$
\begin{aligned}
& w_{i=} \sum_{f=1}^{p} \phi_{f} Z_{f i}+\beta_{t} \\
& \Rightarrow q_{i t=} \delta_{1}+\sum_{j=2}^{k} \delta_{j} Y_{j i t}+w_{i}+\beta_{t}+u_{i t}
\end{aligned}
$$

Given that $w_{i}$ are contemporaneously exogenous to the conditional error such that:

$$
E\left[u_{i t} \mid w_{i}\right]=0, t=1,2, \ldots, T
$$

We impose strict exogeneity on equation (3.3) in order to avert the estimation problem as follows. In this regard, 


$$
\begin{aligned}
& E\left[u_{i t} \mid y_{i 1}, y_{i 2}, \ldots, y_{i T}, w_{i}\right]=0, t=1,2, \ldots, T \\
& \Rightarrow E\left[q_{i t} \mid y_{i t}, w_{i}\right]=\delta_{1}+\sum_{j=2}^{k} \delta_{j} Y_{j i t}+w_{i}+\beta_{t}
\end{aligned}
$$

Thus, the pooled panel model is obtained as:

$$
q_{i t}=y_{i t}^{\prime} \delta+\varphi+u_{i t}
$$

Under the usual assumptions of consistency and unbiasedness, the estimate of $\delta$ is obtained by centering the data between transformation and hence specified the between estimator model as:

$$
\begin{aligned}
& q_{i t}=\delta_{1}+\sum_{j=2}^{k} \delta_{j} y_{j i t}+\varphi+u_{i t} \\
& \bar{q}_{i}=\delta_{1}+\sum_{j=2}^{k} \delta_{j} \bar{y}_{j i}+\varphi+\bar{u}_{i}
\end{aligned}
$$

In effect, the coefficients estimate of $\delta$ uses the cross-sectional deposit money bank data by ignoring the time series deviation. Thus, the pooled estimator becomes:

$\delta_{\text {POLS }}=\delta+\frac{\sum_{i=1}^{N} \sum_{t=2}^{T}\left[q_{i t-1}-\frac{1}{N T} \sum_{i=1}^{N} \sum_{t=2}^{T} q_{i t-1}\right]\left[e_{i t-1}-\frac{1}{N T} \sum_{i=1}^{N} \sum_{t=2}^{T} e_{i t-1}\right]}{\sum_{i=1}^{N} \sum_{t=2}^{T}\left[y_{i t}-\frac{1}{N T} \sum_{i=1}^{N} \sum_{t=2}^{T} y_{i t}\right]^{2}}$

$\Rightarrow \delta_{\text {POLS }}=\delta+\frac{\frac{1}{T} \sum_{t=1}^{T} \frac{1}{N} \sum_{i=1}^{N} q_{i t} e_{i t}}{\frac{1}{T} \sum_{t=1}^{T} \frac{1}{N} \sum_{i=1}^{N} y_{i t}^{2}}$

$\delta_{P O L S}-\delta=\left[\frac{1}{\sqrt{n t}}\right] \frac{G_{N T}}{H_{N T}}$

$$
G_{N T} \stackrel{d}{\longrightarrow} N\left[0, \Omega_{G}^{2}\right], H_{N T} \stackrel{s}{\longrightarrow} Q_{H} \text { as } N, T \rightarrow \infty \text { jointly }
$$

Using the pooled OLS residuals, we estimated the variance-covariance matrix as follows: 


$$
\begin{aligned}
\Omega_{G}^{2} & =\frac{1}{N T} E\left[\sum_{i=1}^{T} \sum_{t=1}^{N} y_{i t} e_{i t}\right]^{2} \\
\Rightarrow & \frac{\sigma_{e}^{2}(i)}{1-\rho_{i}^{2}}\left[\begin{array}{cccc}
\sigma_{1}^{2} & \rho_{i} & \ldots & \rho_{i}^{T-1} \\
\rho_{i} & \sigma_{2}^{2} & \ldots & 0 \\
\rho_{i}^{T-1} & \rho_{i}^{T-2} & \ldots & \sigma_{N}^{2}
\end{array}\right] \\
& =\frac{1}{N T} E\left[y_{11} e_{11}+\ldots+y_{1 T} e_{1 T}+y_{21} e_{21}+\ldots+y_{N T} e_{N T}\right]^{2} \\
& =\frac{1}{N T} E\left[y_{11}^{2} e_{11}^{2}+\ldots+y_{1 T}^{2} e_{1 T}^{2}+y_{21}^{2} e_{21}^{2}+\ldots+y_{N T}^{2} e_{N T}^{2}\right]+E \\
& \Rightarrow \text { cross products }
\end{aligned}
$$

In effect, the error term is a vector white noise generating process with $E\left(e_{t}\right)=0$ and $E\left(e_{t} e_{s}^{\prime}\right)=\left\{\begin{array}{cc}\Omega & s=t \\ 0 & s \neq t\end{array}\right.$ where the covariance matrix $\Omega$ is positive definite implying that the errors are serially uncorrelated but contemporaneously correlated. Given that $E\left[e_{i 1} e_{i 2}\right] \neq 0$ due to contemporaneous correlation, the mathematical expectation of the cross products are themselves not equal to zero. This prompted us to estimate the Newey-West (1987) positive semi-definite, heteroskedasticity and autocorrelation consistent variance-covariance matrix as follows:

$$
\Omega_{G}^{2}=Y^{\prime} \Omega Y+\frac{N}{N-K} \sum_{\ell=1}^{p}\left[1-\frac{\ell}{p+1}\right] \sum_{t=\ell+1}^{N} e_{i} e_{t-\ell}\left[y_{t}^{\prime} y_{t-\ell}+y_{t-\ell}^{\prime} y_{t}\right]
$$

The related t-statistic becomes:

$$
t_{\delta}=\frac{\delta}{\sqrt{\left[\sum_{i=1}^{N} Y_{i}^{\prime} Y_{i}\right]^{-1}\left(\sum_{i=1}^{N} Y_{i}^{\prime} e_{i} e_{i}^{\prime} Y_{i}\right)\left[\sum_{i=1}^{N} Y_{i}^{\prime} Y_{i}\right]^{-1}}}
$$

The analysis is based on a research sample of eight selected Nigerian banks to be precise; First Bank of Nigeria, Zenith Bank, Guaranty Trust Bank and First City Monument bank, . The rationale for choosing the abovementioned banks is the fact that the selected banks constitute the foremost prominent banks in recent time especially when these banks have survived the global economic meltdown, financial shock and bank sector reforms of the CBN.

The study covered the period from 2007 through to 2015. The measurement of variables is as follows: capital adequacy ratio was measured as the ratio of the sum of Tier-One and Tier-Two to risk weighted assets; 
management efficiency of the banks was measured as the ratio of expenditure to totality of income; asset quality of the banks was calculated as the ratio of non-performing assets to advances, liquidity was measured as the ratio of liquid assets to totality of assets.

Research data were obtained from twelve-monthly reports and financial statements of the abovementioned banks and those of the CBN. The study utilized the feasible GLS technique to estimate the pooled model having corrected for heteroskedasticity and serial correlation.

\section{Estimation and results}

The correlation matrix shows that none of the variables in the study exhibited a correlation coefficient above $75 \%$. This indeed demises the problem of multicollinearity amongst the regressors. According to the correlation results, capital adequacy ratio is positively related to profit after tax of the deposit money banks as well as the return on assets while management efficiency and inflation are negatively related to return on assets and profit after tax of the banks.

Table I: Correlation Matrix

\begin{tabular}{|c|c|c|c|c|c|c|}
\hline \multirow[t]{2}{*}{ Variables } & \multicolumn{6}{|c|}{ Correlation Matrix for Return on Assets } \\
\hline & $\log (r)$ & $\log (m)$ & $\log (1)$ & $\log (\mathrm{c})$ & $\log (a)$ & $\log (n)$ \\
\hline $\log (r)$ & 1 & & & & & \\
\hline $\log (m)$ & -.093 & 1 & & & & \\
\hline $\log (1)$ & .176 & 260 & 1 & & & \\
\hline $\log (\mathrm{c})$ & $.698^{*}$ & .197 & .224 & 1 & & \\
\hline $\log (a)$ & -.070 & 017 & -.130 & -.193 & 1 & \\
\hline \multirow[t]{3}{*}{$\log (n)$} & $-.935^{*}$ & .179 & $.759 *$ & -.029 & .048 & 1 \\
\hline & \multicolumn{6}{|c|}{ Correlation Matrix for Bank Profits after Tax } \\
\hline & $\log (b)$ & $\log (m)$ & $\log (1)$ & $\log (\mathrm{c})$ & $\log (a)$ & $\log (n)$ \\
\hline $\log (b)$ & 1 & & & & & \\
\hline $\log (m)$ & -.224 & 1 & & & & \\
\hline $\log (1)$ & $.695^{*}$ & 260 & 1 & & & \\
\hline $\log (c)$ & $.775^{*}$ & .352 & .224 & 1 & & \\
\hline $\log (a)$ & .117 & $.957 *$ & -.130 & -.193 & 1 & \\
\hline $\log (n)$ & $.783 *$ & .179 & $.826^{*}$ & -.029 & .048 & 1 \\
\hline
\end{tabular}

The feasible GLS regression estimates are as detailed in Table II. The estimates for return on assets and bank profit after tax. The coefficient of capital adequacy ratio $(0.136)$ is statistically significant for return on assets. This implies that a $16 \%$ percent increase in capital adequacy enhances the performance of the deposit money banks up to the tune of 2.176 percent. The estimated capital adequacy ratio is below $30 \%$, it indicates that the banking system of the Nigerian economy is yet to grow stronger and as such the deposit 
money banks might not be able to fulfil the liabilities, operational risk, credit risk and market risk.

Table II: Feasible GLS Regression Results

\begin{tabular}{|c|c|c|c|c|}
\hline \multirow[t]{2}{*}{ Regressors } & \multicolumn{2}{|c|}{$\begin{array}{l}\text { FGLS Estimates for Return on } \\
\text { Assets }\end{array}$} & \multicolumn{2}{|c|}{$\begin{array}{c}\text { FGLS Estimates for Bank Profit } \\
\text { after Tax }\end{array}$} \\
\hline & Coefficients & Probability & Coefficients & Probability \\
\hline $\mathrm{C}$ & $\begin{array}{c}-.685^{* *} \\
(.270)\end{array}$ & .004 & $\begin{array}{l}-4.732 \\
(4.30)\end{array}$ & .000 \\
\hline $\operatorname{Ln}(m)$ & $\begin{array}{l}-.925 \\
(.633)\end{array}$ & .002 & $\begin{array}{c}.263 \\
(7.514)\end{array}$ & .038 \\
\hline $\operatorname{Ln}(1)$ & $\begin{array}{l}.350 * * \\
(.112)\end{array}$ & .000 & $\begin{array}{l}1.136 * * \\
(.529)\end{array}$ & .000 \\
\hline $\operatorname{Ln}(\mathrm{c})$ & $\begin{array}{l}.136^{* *} \\
(.048)\end{array}$ & .003 & $\begin{array}{l}.038^{* *} \\
(.019) \\
\end{array}$ & .004 \\
\hline $\operatorname{Ln}(a)$ & $\begin{array}{l}-.526 * * \\
(.242)\end{array}$ & .000 & $\begin{array}{l}-.126 \\
(.082)\end{array}$ & .000 \\
\hline \multirow[t]{3}{*}{$\operatorname{Ln}(n)$} & $\begin{array}{c}-1.058^{*} \\
(.144)\end{array}$ & .000 & $\begin{array}{c}-1.050 * * \\
(.502)\end{array}$ & .000 \\
\hline & \multicolumn{2}{|c|}{$\begin{array}{c}\text { Adjusted } \mathrm{R}^{2}=.592 \\
\mathrm{DW}=2.014, \mathrm{~F}=206.5 \\
\text { Included observations: } 711 \text { after } \\
\text { adjustment }\end{array}$} & \multicolumn{2}{|c|}{$\begin{array}{c}\text { Adjusted } \mathrm{R}^{2}=.542 \\
\mathrm{DW}=2.564, \mathrm{~F}=376 \\
\text { Included observations: } 711 \text { after } \\
\text { adjustment }\end{array}$} \\
\hline & \multicolumn{4}{|c|}{$\begin{array}{l}\text { 1. The values in parentheses are the related Newey-West standard } \\
\text { errors } \\
\text { 2. *(**) indicates statistical significance @ } 1 \%(5 \%) \\
\text { 3. The variance-covariance matrix for the FGLS model is adjusted for } \\
\text { data clustering }\end{array}$} \\
\hline
\end{tabular}

The asset quality coefficient (-0.526) is significant in its adverse effect on Nigerian bank performance. This goes to show that the Nigerian banks have been confronted with the crisis of non-performing assets. In other words, the loans offered by the banks have not significantly yielded positive returns and hence hampered the deeds of these banks.

The coefficient of liquidity $(0.250)$ passes the significance test in both regressions. Thus, it can be inferred that a $16 \%$ increase in the banks' liquid assets enhances the activities of the banks by 4 percent. In effect, the empirical evidence holds that liquid assets have significant influence on the deeds of banks in Nigeria.

The coefficient of efficiency (-0.925) is significant in impeding the deeds of the Nigerian banks. As it were, 16\% rise in the bank efficiency reduces the performance of the banks by 14.8 percent. In effect, the empirical evidence upholds the fact that the bank management is highly inefficient and by extension, the deposit money banks have low financial strength to envelop all operating expenses from earned income.

The coefficients of inflation rate (-1.058) and (-1.050) are statistically significant in slowing down the deeds of Nigerian banks. This goes to show 
that that the performance of deposit money banks in Nigeria have not been favoured by macroeconomic stability as made evident in high inflation rate. Evidently, aside bank specific or internal factors, external factors that characterized the Nigerian economy have not been positive effect on the Nigerian banks' activities.

In accordance with the analysis, variation in bank performance as measured by return on assets and profitability after tax payments is to a large extent as a result of the variation in capital adequacy ratio and liquidity. However, the variation due to management efficiency and inflation do not account positively for bank performance $n$ Nigeria.

The presence of serial correlation was denied by the regression for return on assets given a Durbin-Watson test statistic of 2.014 which is within the acceptable limit for zero autocorrelation. Hence, the policy stance of the study is driven mainly by the feasible GLS estimates for return on assets. The standard error test results are given in Table III.

Table III: Significance Test Based on Newey-West V-C Estimates

\begin{tabular}{|c|c|c|c|c|}
\hline Regressors & $\delta_{i}$ & $S\left(\delta_{i}\right)$ & $\begin{array}{c}\text { Implication } \\
\frac{1}{2} \delta_{i}>S\left(\delta_{i}\right)\end{array}$ & Decision \\
\hline Ln(m) & 0.925 & 0.633 & $0.462<0.633$ & Insignificant \\
\hline Ln(l) & 0.350 & 0.112 & $0.175>0.112$ & Significant \\
\hline Ln(c) & 0.136 & 0.048 & $0.068>0.048$ & Significant \\
\hline Ln(a) & 0.526 & 0.242 & $0.263>0.242$ & Significant \\
\hline Ln(n) & 1.058 & 0.144 & $0.529>0.144$ & Significant \\
\hline $\begin{array}{c}\text { Calculated DW } \\
\left(\mathrm{d}^{*}\right)\end{array}$ & $\begin{array}{c}\text { Lower limit } \\
\text { DW }\left(\mathrm{d}_{\mathrm{L}}\right)\end{array}$ & $\begin{array}{c}\text { Upper } \\
\text { (imit DW } \\
\left(\mathrm{d}_{\mathrm{U}}\right)\end{array}$ & $\mathrm{d}^{*}<\mathrm{d}_{\mathrm{L}}$ and $\mathrm{d}_{\mathrm{U}}$ & Decision \\
\hline 2.014 & 1.568 & 1.892 & No & Accept $\mathrm{H}_{0}$ \\
\hline
\end{tabular}

From the table above, only capital base and liquidity ratio of the banks are significant determinants of the variation in return on equity at $5 \%$ level of significance, using a two-tail test. The implication of the result is that as capital base of the banks increase, it significantly increases the return on assets.

The summary of the t-statistics of the related Newey-West variancecovariance estimates shows significant parameter estimates for capital adequacy ratio and liquid assets of the deposit money banks. Given that the alternative hypothesis is expressed in the form of $\delta_{i} \neq 0$, a two-tail critical region was utilized whereby each tail corresponds to half the chosen level of significance with the area equal to $25 \%$.

The decision rule was to accept the null hypothesis if the absolute tstatistic(s) is (are) greater than the estimated t-statistic(s), otherwise, we reject the null hypothesis. The test shows that the capital adequacy ratio and liquid 
assets are the policy variables for explaining the variation in return on assets at five percent error margin.

The result of ' $F$ ' distribution test at five percent shows that the estimated pooled model could stand the test of time in explaining the variation in return on assets due to the overriding effect of the capital adequacy ratio and liquid assets of the deposit money banks. Using the $d^{*}$ statistic at five percent critical value, the null hypothesis is accepted indicating that the variance-covariance estimates are consistent and consequently the residual variances are serially independent.

\section{Conclusion and policy stance}

The study examines the degree of significance of the capital adequacy ratio in influencing the financial deeds of Nigerian banks. Going by the feasible GLS estimates, the coefficient of asset quality though significant, had a negative impact on the deeds of Nigerian banks. This empirical evidence could be signally the fact that the banking system in Nigeria has an enormous percentage of non-performing loans and this is a constraint on financial performance.

Further, the empirical evidence supports the overriding effect of capital adequacy ratio and liquidity in enhancing the deeds of Nigerian banks. However, the impact of estimated capital adequacy ratio is below $30 \%$. It indicates that the deposit money banks might not be able to fulfil liabilities and risk. The upshot of the analysis is that depositor's money and the confidence of the banking sector have not been absolutely assured.

In the light of our findings, the policy stance of the study the followings: First, the Central Bank of Nigeria and the regulatory authority of the banking system in Nigeria should regularly reassess the least capital that is required of banks in order to enhance their financial deeds in the country. Second, the CBN should be more proactive in implementing policies that can cushion the risk management framework of the all the deposit money banks in Nigeria. Third, there is need to implement macroeconomic policy of low inflation as this could enhance a favourable macroeconomic environment conducive to financial performance in the country.

\section{References:}

Abreu, M. and Mendes, V. (2002), Commercial Bank Interest Margins and Profitability: Evidence from E.U Countries. Working paper Series, Porto Athansasoglou, P., Brissimis, S. and Delis, M. (2006), "Bank-specific, industry-specific and macroeconomic determinants of bank profitability. Journal of International Money and Finance, Vol. 19, No. 6, pp. 813-832. 
Al-Sabbagh, Noor (2004), "Determinants of capital adequacy ratio in Jordanian and Evidence", Journal of Monetary Economics, Vol. 32, pp. 513542

Dore, M. (2013), An Empirical Analysis of Bank Profitability in Ghana: Evidence from Bank Specific and Macroeconomic Factors. Eastern Mediterranean University (EMU).

Ho, Shirley J. and Hsu, Su-Chu (2010), "Leverage, Performance and Capital Adequacy ratio in Taiwan's Banking Industry, Japan and the World Economy, Vol. 22, pp. 264-272.

Isik, I., and Hassan, M.K, (2003a), Efficiency, Ownership and Market Structure, Corporate Control and Governance in the Turkish Banking Industry. Journal of Business Finance and Accounting, 30, 1363 - 1421.

Kosmidou, K. (2008). The Determinants of Banks' Profits in Greece during the Period of EU

Financial Integration. Managerial Finance 34(3): 146-159.

Mpuga, P. (2002), The 1998-99 Banking crises in Uganda: What was the Role of the New

Capital Requirements? International Journal of Financial regulation and compliance,

10(3), 1145-1168

Naceur B. S. (2003), The determinants of the Tunisian banking industry profitability: panel

Evidence, Paper presented at the Economic Research Forum (ERF) 10th Annual

Conference, Marrakesh-Morocco, and 16-18 December

Newey, W. K., and K. D. West (1987), A simple, Positive Semi-definite, Heteroskedasticity and Autocorrelation Consistent Covariance Matrix. Econometrica 55: 703-708.

Obamuyi, T. M., (2011): Incessant Bank Distress and the Policies of Central Bank of Nigeria. International Journal of Finance and Accounting, 1(1), 121 $-13$

Osuka, B.O., and Richard, O.C., (2013): The Determinants of Financial Performance of Quoted Banks in Nigeria: A Study of Selected Deposit Money Banks (DMBs) (2001-2010). International Journal of Education and Research, Vol. 1, No. 10, pp.1-18, October

Perera, S., Skully, M., and Chaudrey, Z. (2013): Determinants of Commercial Bank Profitability: South Asian Evidence. Asian Journal of Finance and Accounting, 5(1), 365-380.

Riaz, S., and Mehar, A. (2013). The Impact of Bank Specific and Macroeconomic Indicators 
on the Profitability of Commercial banks. Romanian Economic Journal, 16(47), 91-110.

Saona, P. H., (2011), Determinants of the Profitability of the US Banking Industry. International Journal of Business and Social Science, 2(22), 255 269.

Scott, J. W., and Arias, J. C., (2011): Banking Profitability Determinants. Business Intelligence Journal, 4(2), 209-230

Somoye, R.O.C., (2008), The performance of commercial banks in postconsolidation period in Nigeria: An Empirical Review. European Journal of Economics, Finance and Administrative Sciences, 14, 62-73.

Sufian, F., (2009), Determinants of Bank Profitability in a Developing Economy: Empirical Evidence from Bangladesh. Journal of Business Economics and Management, 10(3), 207-217.

Tomola, M.O., (2013), Determinants of Banks' Profitability in a Developing Economy: Evidence from Nigeria. Organizations and Markets in Emerging Economies, Vol.4, No.2 (8), pp.97-111 